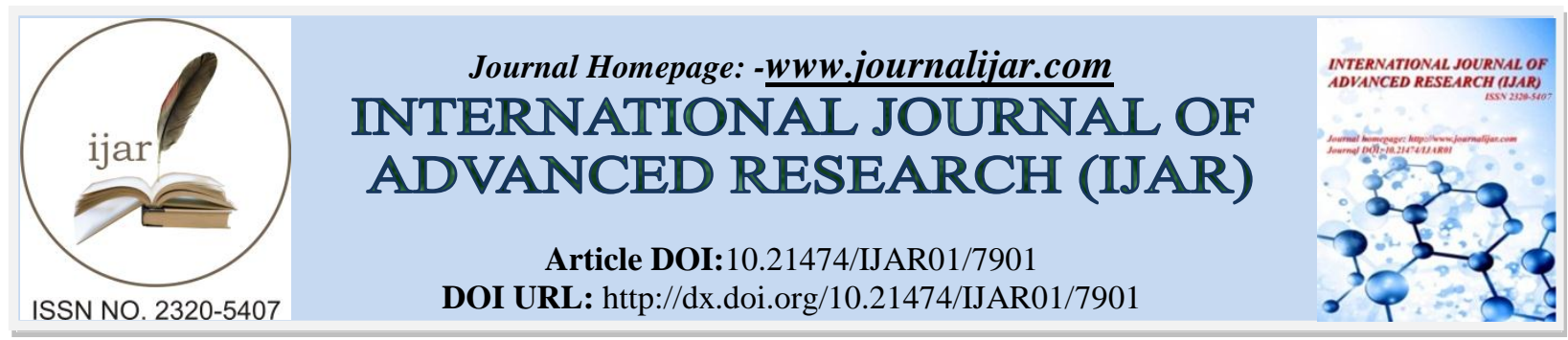

RESEARCH ARTICLE

\title{
A CRIMINAL LIABILITY IN THE PROCUREMENT OF GOVERNMENT GOODS AND SERVICES THROUGH E-PROCUREMENT SYSTEM.
}

Tantu, andi Sofyan, M. Syukri Akub and Syamsul Bachri.

Graduate School, Hasanuddin University, South Sulawesi, Indonesia.

\section{Manuscript Info}

\section{Manuscript History}

Received: 12 August 2018

Final Accepted: 14 September 2018

Published: October 2018

Keywords:-

Criminal Law; e-Procurement; Goods and Services.

\begin{abstract}
Electronic system of e-procurement indicates an important development for the purchasing process, offering benefits to the organization through the efficiency of the purchasing process and reducing prices. However, there are several forms of corruption that commonly performed in the procurement process of goods and services both overtly or not. A factor of the high level of local government' corruption, especially by regional heads is related to political cost. The research is a normative research. The results show that the criminal liability in the procurement of government goods and services through the e-procurement system still has a number of weaknesses. However, it has not been supported by an effective supervision system. Law enforcement for corruption act in the sector of the procurement of goods and services cannot only prioritize enforcement which has proven costly. However, it must be balanced with preventive aspects that can anticipate or minimize corrupt practices in the procurement of goods and services. Enforcement and prevention must analogously, if there are enforcement, then recommendations for improvement must also be conducted.
\end{abstract}

Copy Right, IJAR, 2018,. All rights reserved.

\section{Introduction:-}

The development of facilities and infrastructure to support the economy and service of the people in Indonesia is a necessity. Essentially, the procurement of goods and services is an effort by the user to obtain or realize the goods and services they want, so that each party must subject to the prevail ethics and regulations. ${ }^{1}$ One of the distributions of State budget is through the procurement of government goods and services. This procurement is a fundamental component of good governance.

Considering the financing of the procurement of government goods and services as government expenditure that uses State budget in which comes from taxes from every Indonesian citizen. The regulation is intended for the procurement of goods and services has accountability and without reducing effectiveness in its implementation. In the posture of the State budget and Regional budget in 2017, it seems the procurement of goods and service is very large. This budget every year according to LKPP is around $40 \%$ of the State and Regional budgets. It is intended to the procurement activities in order to support national economic activities (see table 1).

${ }^{1}$ Lubis, A.S. "Aspek Hukum dalam Pengadaan Barang dan Jasa Pemerintah", (Paper). Available at: http://www.bppk.kemenkeu.go.id/ Accessed on 10 May 2018. 
Table 1:-The posture of State and Regional budgets for the procurement of good and services in 2015, 2016 and 2017

\begin{tabular}{|c|c|c|c|}
\hline State Budget 2017 & Nominal (Billion) & Regional Budget 2017 & Nominal (Billion) \\
\hline $\begin{array}{c}\text { Expenditure of good and } \\
\text { service }\end{array}$ & $296 \mathrm{~T}$ & $\begin{array}{c}\text { Expenditure of good and } \\
\text { service }\end{array}$ & $232 \mathrm{~T}$ \\
\hline $\begin{array}{c}\text { State Budget 2016 } \\
\text { Expenditure of good and } \\
\text { service }\end{array}$ & Nominal (Billion) & Regional Budget 2016 & Nominal (Billion) \\
\hline State Budget 2015 & 315 T & $\begin{array}{c}\text { Expenditure of good and } \\
\text { service }\end{array}$ & $\mathbf{3 0 5}$ T \\
\hline $\begin{array}{c}\text { Expenditure of good and } \\
\text { service }\end{array}$ & $815,8 \mathrm{~T}$ & Regional Budget 2015 & Nominal (Billion) \\
\hline
\end{tabular}

Source: Ministry of Finance, 2018

Essentially, the determination of the procurement of the government goods and services is intended for the procurement can be implemented more effectively and efficiently with fair, transparent, open and fair competition, so the results can be accounted for both in terms of physical, financial and public services. Legal instruments for the procurement of goods and services have also been amended several times, from Presidential Regulation No. 54 of 2010 and its amendments, to the Presidential Regulation No. 16 of 2018, all of which have emphasized the use of electronic auction systems or e-procurement, no longer manually that can arise corrupt practices. If referring to the Presidential regulation, every agency from the central to the regional level is obliged to use the e-procurement system.

Through the implementation of e-procurement, transparency is guaranteed by information openness about procurement that can be known by all providers who meet the requirements specified by the ULP. Competition is guaranteed by increasing market access for providers to compete to offer goods and services. The objective of decision making is ensured by the openness of evaluation results so that discrimination between providers and method clarity in the evaluation of bids can be eliminated.

By the procurement of goods and services electronically (e-procurement) is expected to increase transparency, so that fair competition between business actors can be more quickly and the procurement process of government goods and services electronically will further improve and ensure efficiency, effectiveness, transparency and accountability in State expenditure. Engstorm et al. ${ }^{2}$ argues that in the private sector, generally the e-procurement provides annual cost savings 25 to 50 percent and has the potential to reach the same level in the public sector.

The supporters of e-procurement argue that this system helps governments to save money and provide a more accountable, more effective, and faster way to manage procurement. ${ }^{3}$ Electronic system of e-procurement indicate an important development for the purchasing process, offering benefits to the organization through the efficiency of the purchasing process and reducing prices. ${ }^{4}$

However, in its implementation, there are often various irregularities in the procurement of Government goods and services, even though implement e-procurement system. Based on various existing data, the loss of State finances caused by irregularities in the provision of the procurement of Government goods and services its value is very large. According to the Audit Board' data presents that if seen from the expenditure of government goods and services, there is a leak in approximately $30 \%$ or 25 billion rupiah. This figure is calculated only based on the central government budget and has not been calculated with the regional government budget. ${ }^{5}$ This is in accordance with

\footnotetext{
${ }^{2}$ Engstorm, Anne et. al.. (2009). "Implementation of Public E-Procurement in Swedish Government Entities". Proceedings of the International Multiconference on Computer Science and Information Technology.

${ }^{3}$ Gunasekaran, Angappa and Eric W.T. Ngai. (2008). "Adoption of E-procurement in Hong Kong: An Empirical Research". International Journal of Production Economics. 113.

${ }^{4}$ Croom, Simon R., and Alistair Brandon-Jones. (2005). Key Issues in E-Procurement: Procurement Implementation and Operation in the Public Sector, Journal of Public Procurement. vol. 5. issues 3.

${ }^{5}$ Amirudin. 2012 "Analisis Pola Pemberantasan Korupsi dalam Pengadaan Barang dan Jasa", Jurnal Kriminologi Indonesia Vol. 8 No.1 Mei 2012 : 026 - 037.
} 
Kaufman' research that the procurement of goods and services is an activity of the government which is considered the most vulnerable to corruption, and this happens anywhere in the world. ${ }^{6}$

There are several forms of corruption that commonly performed in the procurement process of goods and services both overtly or not. A factor of the high level of local government' corruption, especially by regional heads is related to political cost. Especially if the regional head is a leader of political party or has political affiliation with certain political parties in the region, then the Regional budget becomes the most vulnerable gap. The incumbent regional head, for example, will use his power to collect political costs, one of them through the procurement of goods and services, to finance his candidacy again, or relatives who fight in the elections. As well as will be done after being elected and active.

These cases raise big questions about the application of e-procurement systems in the process of the procurement of goods and services in the regions. Certainly, it invites the vulnerability for the procurement office in the region. The vulnerability is very easily intervened by the regional head or legislative and related parties with personal interests in the process of the procurement of government goods and services which should be intended for the benefit of the people.

\section{Method of Research}

The research is a normative research. ${ }^{7}$ It is a problem approach that has the purpose and objective to examine the legislation in the field of procurement of goods and services, as well as its institutional aspects. The collection of legal materials used in this research is to use literature study methods to obtain primary and secondary materials. The processing and analysis of the legal material is very substantial in legal research because the legal materials are descriptive.

\section{Criminal Liability for the Procurement of Government Goods and Services}

The Corruption Eradication Commission records that almost 80 percent of corruption cases are handled by the Corruption Eradication Commission from the procurement of goods and services. ${ }^{8}$ In 2016, the annual report of the Corruption Eradication Commission states that the sector of the procurement of goods and services is a vulnerable point for corruption, in addition to the sector or field of planning and management of Regional budget, as well as licensing services. ${ }^{9}$ Furthermore, a data reported by Transparansi Internasional Indonesia (TII) in 2006 shows that the number of the procurement of goods and services in public institutions reaches around 15\%-30\% of GDP (Gross Domestic Product). The more of the procurement of goods and services in government institutions from the center to the regional level gives opportunities for corruption, due to corruption in the procurement of goods and services, the government reach 10\%-20\% losses based on a normal scale, and in some cases the amount of State losses up to $40 \%-50 \%$ of the contract value.

The procurement occurs due to the need for goods or services, from small goods such as stationery to large goods such as transportation equipment required by government agencies or institutions, and also the need for services such as consulting services in fields such as finance, law and the need for survey services and population censuses.

There are several forms of corruption that are commonly performed in the procurement of goods and services both overtly or not, as follows:

1. Bribery and facilitation money. It usually in a large number of bribery cases and it given to decision-making officials, while facilitation money is given in smaller amounts to low-ranking employees (positions).

2. Supply and Demand. It is a mutual relationship between the giver and recipient of bribe, because corruption will occur if the two factors meet each other.

3. Cartel and Collusion. A cartel is formed to manipulate a tender process that benefits the cartel members, while collusion is a form of agreement from the tender participants to determine the winner of the tender or payment of compensation to the losing party.

\footnotetext{
${ }^{6}$ OECD. 2007. "Integrity on Public Procurement, Good Practices from A to Z". Paris. Tersedia pada: Piga, G. "A Fighting Chance Against Corruption in Public Procurement?" pada Rose-Ackerman, S. and Soreide, T. (eds.) 2011. International Handbook on the Economics of Corruption, Volume Two, Edward Elgar, Cheltenham

${ }^{7}$ Marzuki, P.M. 2010. Penelitian Hukum. Jakarta: Kencana. hlm 35; compared to Morris L. Cohen dan Kent C. Olson, Legal Reserach in A Nutshell, West Publishing Company, St. Paul Minnesota, p. 1-3.

${ }^{8}$ Source: Kompas.com (28/9/2017)

${ }^{9}$ Annual Report of the Corruption Eradication Commission, 2016.
} 
4. Structure and Situational. Structural corruption is a corruption that has been planned and prepared carefully and systematically, while Situational corruption is unplanned corruption.

In general, the implementation of the procurement of goods and services can be grouped based on the stage of activity. The pattern of irregularities that occurred during the preparation and signing of the contract was the signing of a contract that was not supplemented by supporting documents or fictitious documents and the signing of a contract that was postponed because of a guarantee that did not yet exist. ${ }^{10}$ The pattern of irregularities that occur during the implementation phase of the contract and the delivery of goods and services is that the goods delivered are not in accordance with the specifications in the contract and signatories to the minutes of handover even though the work has not been completed, usually this is done at the end of the fiscal year.

Depart from the irregularities above, it can be identified patterns of corruption in the procurement of goods and services are (a) abuse of authority, (b) bribes by providers of goods and services, (c) collusion, whether between officials, or between officials with providers of goods and services, or between providers of goods and services.

Factors that make the procurement of goods and services as a fertile field for corruption practices, including the amount of money in circulation, closed contact between service providers and the auction committee and the number of auction procedures that must be followed. This procurement process despite the existence of indications of corruption, collusion and nepotism, but the verification is very difficult because the administration system of the giver and recipient of this job is very neat. To overcome this problem, an open process is needed in the procurement of goods and services. This transparent process will provide equal opportunities to the providers of goods and services and in the implementation will get supervision from the community. ${ }^{11}$

There are 3 (three) factors that can be categorized as a criminal act in the procurement of goods and services are, the first abuse their authority; the second, provide benefits to both yourself and others; and the third, causing losses to the State finances. If the process is in progress, although not final, but there are indications or "strong suspicions" of irregularities then it can be categorized as violations to the corruption laws.

The following are some actions that can trigger criminal acts in the procurement of government goods and services, including: first, bribery. Bribing is an attempt by someone to influence government officials (decision-makers) to take certain actions or not to take certain actions by giving money or other valuable objects. It is a crime that belonging the type of corruption act and this action is very old. Bribery as an everyday term contained in the law is a gift or promise ("giften" or "beloften") to given or received. The actor of bribery is categorized as active bribing (active omkoping) as a type of bribery in which the actor as a gift giver or a promise, while passive bribing (passive omkoping) as a type of bribery in which the actor as gift recipient or a promise.

The end of collusion is the elimination of competition in the procurement of goods and services. Competition in public procurement means that providers independently compete to offer goods and services in an election process. A healthy competition is a key element that will produce the most profitable offer for the government, especially the lowest price and the best quality of goods. For providers, the competition serves as an important driver of the growth of innovation in goods and services to produce the best products at competitive prices. It can only be achieved if there is no collusion in tenders, as a most prominent problem in procurement corruption in the public sector. Providers will compete healthy when they are sure that they are provided with all the same information and will be evaluated by non-discriminatory evaluation methods, as well as a mechanism for refuting the evaluation results.

Two corruption cases in the procurement of goods and services involving Regional Heads in 2018, for example, Hand Arrest Operation the Major of Kendari Adriatma Dwi Putra, with his father, Asrun (the candidate for Governor of Southeast Sulawesi). Adriatma allegedly received bribes from the President Director of PT. Sarana Bangun Nusantara, Hasmun Hamzah, worth Rp 2.8 billion. Bribery is related to the project of the procurement of goods and services in Kendari district in 2017-2018. The bribe money was allegedly used for the political costs of his father as candidate for Governor of Southeast Sulawesi in election 2018.

\footnotetext{
${ }^{10}$ Sutedi, Adrian. Aspek Hukum Pengadaan Baran dan Jasa dan Berbagai Permasalahannya. Jakarta : Sinar Grafika, 2008, Pages 126-127.

${ }^{11}$ Muhammad Jasin et al. "Memahami untuk melayani, Melaksanakan E-Announcement dan E-Procurement dalam Sistem Pengadaan Barang dan Jasa”. Jakarta: Komisi Pemberantasan Korupsi, 2007, p. 27
} 
The findings of LKPP are also not much different. There are still many practices of tender conspiracy, both vertically and horizontally despite using e-procurement. The vertical conspiracy is an indication that the problem of fraud occurs not only from the management official, but also from the provider. ${ }^{12}$ Its findings in 2015-2017, there were 6.682 packages that failed to auction with details of $41 \%$ in the field of construction, $23-32 \%$ in the field of procurement of goods, and $14-25 \%$ in the field of consulting services. He explained that the failure of the auction was due to the offer not meeting the administrative requirements, the participants did not pass the technical evaluation, and no one entered the bidding document.

The determination of the procurement of government goods and services is intended can be conducted more effectively and efficiently with fair, transparent, open competition so that the results can be accounted for in terms of physical, financial and benefits for public services. Legal instruments for conduct the procurement of goods and services have also been amended several times, from Presidential Regulation No. 54 of 2010 to No. 16 of 2018, all of which have emphasized the use of an electronic auction system or e-procurement, no longer manually opening the corruption practices. Hence, referring to the Presidential Regulation, every agency, from the central to the regional level is obliged to use the e-procurement system.

\section{Designing A Corruption Prevention for the Procurement of Government Goods and Services}

The United Nations Office on Drugs and Crime (UNODC) in the Guidebook on anticorruption in public procurement and the management of public finances explained there were 3 (three) key elements required to prevent corruption in the procurement of goods and service. They are transparency, competition and objective decisionmaking. ${ }^{13}$

Efforts by the Government of Indonesia to design corruption prevention in the procurement of goods and services, such as (i) designing procurement organizations with a more horizontal structure, so that fellow officers can control each other; and (ii) designing the procurement of goods and services electronically, especially electronic purchasing that allows the purchase of goods in an effective way and reduces the potential for manipulation in the tender process.

There are several key requirements for successful prevention in the procurement of goods and services, namely: First, transparency. As the Presidential Regulation No. 54 of 2010 and its amendments, to No. 16 of 2018, one of the objectives of implementing electronic auctions (e-procurement) is to increase transparency and accountability. By implementing e-procurement, information openness about procurement can be known by all qualified providers. Second, competition. Competition in public procurement means that providers independently compete to offer goods and services in an election process. The implementation of e-procurement will increase market access for providers to compete to offer goods and services. There will be no more restrictions on providers only for certain districts that we used to meet in the auction beforehand, because by e-procurement the competition became borderless. By increasing this market access, it will create healthy competition in the procurement of goods and services.

Third, the objectivity in decision-making. UNODC ${ }^{14}$ establishes objectivity in procurement decision-making as one of the important bases in determining the anti-corruption system in procurement. Objectivity in decision-making in the context of public procurement refers to the maximum effort to reduce or eliminate subjective bias, prejudice and evaluation. The principle of objectivity in the procurement of public sector is closely related to the principle of nondiscrimination and equality for providers. It means that there is no discrimination between the providers of goods and services unless it is justified based on relevant objective considerations.

Hence, through the implementation of e-procurement, the objectivity is maintained in various ways, the necessity to upload procurement documents, addendum of procurement documents and evaluation results on the website can

12 Source: Kompas News. "KPK: E-Procurement Belum Menjamin Pengadaan Barang dan Jasa Bebas Korupsi”, Available online at: https://nasional.kompas.com/read/2016/08/24/11260361/kpk.eprocurement.belum.menjamin.pengadaan.barang.dan.jasa.bebas.korupsi Accessed on 11 May 2018.

${ }^{13}$ United Nations Office on Drugs and Crime. 2013. "Guidebook on anti-corruption in public procurement and the management of public finances”, Source: https://www.unodc.org/documents/corruption/Publications/2013/Guidebook_on_anticorruption_in_public_procurement_and the management_of_public finances.pdf, Accessed on 14 April 2018. ${ }^{14}$ UNODC, loc.cit. 
guarantee the disclosure of all criteria for participation and provider qualifications, rules regarding technical specifications, evaluation results. It is to ensure that procurement entities do not discriminate between providers and clarity of methods in evaluating bids.

In general, legal politics is understood as the process of establishing and implementing a system or legal order that regulates the lives of people in the country nationally. So, the understanding of legal politics does not only mean the establishment of law through the establishment of legal substance as understood so far, but also in the understanding of strengthening law enforcer and the legal structure and the development of legal culture.

The research departs from the postulate that corruption law enforcement should prioritize aspects of prevention, as well as in the process of the procurement of government goods and services. Legal politics of corruption prevention in the sector of the procurement of good and services should be based on 2 (two) main aspects; first, regulatory aspect and second, institutional aspect through the integrated-construction of the procurement institution vertically. In order the National Strategy for Corruption Prevention and Eradication can align that the eradication of corruption prioritizes prevention, and not merely action.

Like corruption in general, the concept of the procurement of good and services, the prevention of corruption must begin from detecting the origin of corruption. Referring to the concept developed by the Association of Certified Fraud Examiners, ${ }^{15}$ it is relevant to describe the issue of corruption prevention from the fraud diamond theory. In essence, this theory states that corrupt behavior (abuse) can occur because 4 (four) things: (i) impulse on the employees to misuse money and institutional assets; (ii) circumstances that allow employees to commit abuse; (iii) employee' mindset and ethics that allows them to commit abuse; (iv) the capacity of employees to make their crimes undetectable by the system.

As above, according to Greyclar and Prenzler, ${ }^{16}$ corruption can be prevented in 5 (five) ways, namely: (i) complicating efforts to commit corruption; (ii) reduce the causes that tolerate or allow corruption; (iii) increase the detected risk; (iv) reduce incentives for corruption; and (v) reduce the provocation for corruption.

During this, massive corruption in Indonesia was addressed by a criminal law approach that was repressive and action-oriented. So that many views that this makes law enforcement become counterproductive, because energy is focused more on enforcement and not prevention ("the healing of problems") contained in the system. An overuse repressive approach raises concerns for the State apparatus to take action and/or innovation. In the context of the procurement of goods and services, this repressive approach actually makes the State apparatus afraid to be involved in procurement activities, so they try to make themselves not eligible to be chosen as parties involved in procurement by thwarting themselves in national tests. ${ }^{17}$

Actually, the procurement of goods and services should be implemented credibly through good, independent, fair, transparent, professional and competitive arrangements. So, if all of that is implemented it can prevent corruption, collusion and nepotism and the climate of unfair business competition because the conspiracy between government officials and providers of goods and services. ${ }^{18}$

Indonesia Corruption Watch (ICW) in 2010 formulated the concept of preventing corruption in the sector of the procurement of goods and services. The first, the legal framework must accommodate clear rules, eliminate

\footnotetext{
${ }^{15}$ Kassem, R and Higson, A. 2012. "The New Triangle Model" Journal of Emerging Trends in Economics and Management Sciences (JETEMS) 3(3). Kim, D., Nugroho, H.P., and Afifi, A. "Enhancing Efficiency of National Budget Execution through Advanced Public Procurement System", Korea Development Institute dan Ministry of Strategy and Finance of the Republic of Korea, 2013. Policy Consultation to Strengthen Indonesian Economy's Capacity, Korea

${ }^{16}$ Graycar, A. and Prenzler, T. "Understanding and Preventing Corruption.” Basingstoke: Palgrave Macmillan, 2013. Page 72.

${ }^{17}$ Richo Andi Wibowo, (Fakultas Hukum Universitas Gadjah Mada dan Utrecht University School of Law), "Mencegah Korupsi Pengadaan Barang Jasa (Apa Yang Sudah Dan Yang Masih Harus Dilakukan?)", https://acch.kpk.go.id/id/ragam/riset-publik/mencegah-korupsi-pengadaan-barang-jasa-apa-yang-sudah-dan-yangmasih-harus-dilakukan, Accessed on 10 May 2018.

${ }^{18}$ Agus Kuncoro, Begini Tender Yang Benar, (Yogyakarta: Primaprint, 2013), Page. 3
} 
discretion, comprehensive and transparent. In a local context, the local government can independently build a transparent and accountable in the system of the procurement of goods and services under the auspices of the Regional Regulation; the second, increasing business competition; the third, facilitate and open simple, fast and fixed rules or procedures; the fourth, establish independent auction committees, especially the intervention of officials above them; the fifth, open the opportunities for the public to supervise the tender process by providing all information and documents needed for supervisory work, clearly dividing tasks and responsibilities, the existence of definite authority so as to improve the accountability of the auction system; the sixth, promote the function of complaint mechanism, both delivered by the auction participants and the public who oversee; the seventh, enforcing strict sanctions, both administrative and legal for companies or employers and government officials who play and commit fraud in the auction (company blacklist); the eighteenth, reduce the auction system which opens opportunities for parties. ${ }^{19}$

The Directorate of the Research and Development of the Corruption Eradication Commission has conducted efforts to prevent the corruption in the procurement of goods and services by conducting research. The research departs from mapping the root of problems related to the procurement of goods and services. Mapping vulnerable points on regulation; implementation, supervision and budgeting related to the procurement of government goods and services; prepare recommendations to close the critical point on planning, implementing and monitoring the procurement of government goods and services; and preparing recommendations for strategic recommendations related to corruption prevention in the procurement of goods and services nationally.

Then, the research gave birth to recommendations; strategic and technical. Strategic in terms of recommendations for comprehend the system of the procurement of goods and services nationally; 1) Centralization study of the procurement of goods and services with certain constraint; 2) Integration of Planning and Budgeting of the procurement of goods and services. While, technical in terms of technical implementation as supporting for comprehend the procurement of goods and services nationally; 1) Development of supporting apparatus; 2) the quality of human resource in the procurement of goods and services; 3) the quality of goods and services providers; 4) Supervision of the procurement of goods and services. ${ }^{20}$ The Corruption Eradication Commission also saw that the Procurement Service Unit which in the Presidential Regulation No. 16 of 2018 was amended to the Work Unit for Procurement of Goods and Services was still vulnerable to intervention. So that the Corruption Eradication Commission will encourage the establishment of special working unit of the procurement of goods and services independently.

The Corruption Eradication Commission and ICW did not mention the strengthening of institutional aspects and how to encourage integrated system of the procurement of goods and services centralized in LKPP. In fact, one of the vulnerable points of the procurement of goods and services in the region is the intervention of regional heads, legislative, and other interest groups. As long as the working unit of the procurement of goods and services is still under the authority of the Regional Government, then the intervention of the procurement of goods and services will continue to occur, one of many reasons is that the procurement of goods and services is a fertile place for political corruption in the region.

In an autonomous legal order, law is seen as an independent institution that is able to control repression and protect its own integrity. ${ }^{21}$ In this case, the independence of the procurement unit in the region will determine the work of the procurement of goods and services which also leads to good results, in the sense that the results of the procurement of goods and services can be ascertained fairly and without intervention. This is in accordance with Romli Artasasmita's view, in his book entitled "Teori Hukum Integratif" that basically the legal function as a tool of social engineering, referring to the legal theory of Roscoe Pound, is relatively still in line with development national law today, but it also needs to be equipped with bureaucratic engineering that puts forward the role model or

\footnotetext{
${ }^{19}$ Adnan Topan Husodo, “Mencegah Korupsi di Bidang Pengadaan Barang dan Jasa Instansi Pemerintah”, Paper presented on Fakultas Hukum Univ. Indonesia, 22 June 2010.

${ }^{20}$ The Study of the Prevention of Corruption for the Procurement of Government Goods and Services, Directorate of Research and Development, 2016.

${ }^{21}$ Philippe Nonet and Philip Selznik, "Law and Society in Transition: Toward Responsive Law”, Harper Colophon Books, Harper \& Row, Publishers, New York, 1978, pages 5 - 7.
} 
leadership, so that the legal function as a tool of engineering can create harmonization between the bureaucratic elements and the community in a container called "bureaucratic and social engineering" (BSE). ${ }^{22}$

Legal reform in the field of the procurement of goods and services, as well as aspects of institutional strengthening are also felt to be very necessary. Thus, this research encourages legal renewal of LKPPs institutional strengthening by establishing LKPP representative in all districts or cities in Indonesia. In addition to the independence of procurement institutions that are structural-hierarchical integrated by LKPP, it is also important is how the supervision mechanism for the integration of the procurement of goods and services. Supervision has an important role in the process of procuring goods and services, because the procurement of goods and services tends to be transactional, making them vulnerable to fraud or corruption. Generally, new irregularities can be known after they occur, there are no preventive actions. A criminal case is known after an external audit or law enforcement process. During the research, the authors found several findings related to the weakness of this supervision.

The first, the weak supervision of the procurement of goods and services, even though the Presidential Regulation has mandated the Ministries/Institutions/ Agencies/Regions to supervise and assign the relevant internal supervisory apparatus to conduct audits in accordance with the provisions. Based on the research, supervision conducted by the audit institution; the Audit Board, BPKP is a financial post-audit every year. While, APIP (Inspectorate) also tends to post-audit, and when there are cases (repressive).

The benchmark study of the Corruption Eradication Commission to the countries that are free from corruption (IPK $>6.00$ ), conduct supervision of the procurement of goods and services in 3 (three) ways: ${ }^{23}$

1. Probity Audit (in Australia and Commonwealth countries)

2. Pre-award audits and contract audits (United States and countries that influence them)

3. The audit is done by internal audits (in many countries).

The second, during this the supervision of the procurement of goods and services has been performed by the APIP/Inspectorate which is also part of the bureaucracy structure of regional government, which is accountable to the Regional Head. As a consequence, the supervision process is not independent because it is possible to intervene from the Regional Head. There may be findings in the process of the procurement of goods and services, but the findings are not processed, because they intersect with the interests of the regional head, or a number of elites in the region.

The third, the supervision of LKPP only to e-purchasing processes on the LKPP site. LKPP cannot monitor the entire of the procurement of goods and services as performed by ULP/UKPBJ in the regions because the institutional problem that are not structural-hierarchical. Indeed, e-purchasing on the LPSE site can be supervised by LKPP, but the process of the procurement of goods and services which starts from planning to the implementation of the tender, escapes the supervision of LKPP. Hence, this research initiated the establishment of the institution/regulatory body of the procurement of goods and services run by LKPP representatives.

The ideal procurement for future is by designing the institutions of the procurement of goods and services in the regions must be integrated in LKPP as the only institution that functions in the process of the procurement of goods and services. Through the revision of the Presidential Regulation of the procurement of goods and services and the Presidential Regulation of LKPP, ULP/UKPBJ in the region is merged into LKPP that will be established in each Province/District/City throughout Indonesia (LKPP representative). As well as, an independent supervisory body will be established in each province to supervise the process of the procurement of goods and services as performed by LKPP representatives.

\section{Conclusion:-}

An aspect of criminal liability in the procurement of government goods and services through the e-procurement system still has a number of weaknesses. The regulation, from the Presidential Regulation No. 54 of 2010 and its amendments to the Presidential Regulation No. 16 of 2018 has indeed implemented an electronic procurement

\footnotetext{
${ }^{22}$ Romli Atmasasmita, Teori Hukum Integratif:Rekonstruksi Terhadap Teori Hukum Pembangunan dan Teori Hukum Progresif; (Bandung: Genta Publshing, 2012).

${ }^{23}$ The Study of the Prevention of Corruption for the Procurement of Government Goods and Services, Directorate of Research and Development, December 2014
} 
system, through e-marketplace and e-purchasing, which can facilitate the process of the procurement of goods and services in the regions. However, it has not been supported by an effective supervision system. Consider the supervision of the procurement of goods and services is still "local-centric", by the Government Internal Supervisory Officials or Inspectorate, which is also part of the bureaucracy structure of the regional government. Finally, the supervision is not effective, still leaving a gap for intervention by the regional head, the legislative, or other interest groups, so that the process of the procurement of goods and services is vulnerable to corruption.

Law enforcement for corruption act in the sector of the procurement of goods and services cannot only prioritize enforcement which has proven costly. However, it must be balanced with preventive aspects that can anticipate or minimize corrupt practices in the procurement of goods and services. Enforcement and prevention must analogously, if there are enforcement, then recommendations for improvement must also be conducted.

\section{References:-}

1. Adnan Topan Husodo, "Mencegah Korupsi di Bidang Pengadaan Barang dan Jasa Instansi Pemerintah", Paper presented on Fakultas Hukum Univ. Indonesia, 22 June 2010.

2. Amirudin. 2012 “Analisis Pola Pemberantasan Korupsi dalam Pengadaan Barang dan Jasa”, Jurnal Kriminologi Indonesia Vol. 8 No.1 Mei 2012 : 026 - 037.

3. Annual Report of the Corruption Eradication Commission, 2016.

4. Croom, Simon R., and Alistair Brandon-Jones. (2005). Key Issues in E-Procurement: Procurement Implementation and Operation in the Public Sector, Journal of Public Procurement. vol. 5. issues 3.

5. Engstorm, Anne et. al.. (2009). "Implementation of Public E-Procurement in Swedish Government Entities". Proceedings of the International Multiconference on Computer Science and Information Technology.

6. Graycar, A. and Prenzler, T. "Understanding and Preventing Corruption.” Basingstoke: Palgrave Macmillan, 2013.

7. Gunasekaran, Angappa and Eric W.T. Ngai. (2008). "Adoption of E-procurement in Hong Kong: An Empirical Research". International Journal of Production Economics. 113.

8. Kassem, R and Higson, A. 2012. "The New Triangle Model" Journal of Emerging Trends in Economics and Management Sciences (JETEMS) 3(3).

9. Kim, D., Nugroho, H.P., and Afifi, A. "Enhancing Efficiency of National Budget Execution through Advanced Public Procurement System", Korea Development Institute and Ministry of Strategy and Finance of the Republic of Korea, 2013. Policy Consultation to Strengthen Indonesian Economy's Capacity, Korea

10. Kompas News. "KPK: E-Procurement Belum Menjamin Pengadaan Barang dan Jasa Bebas Korupsi”, Available online at: https://nasional.kompas.com/read/2016/08/24/11260361/kpk.eprocurement.belum.menjamin.pengadaan.barang.dan.jasa.bebas.korupsi Accessed on 11 May 2018.

11. Lubis, A.S. "Aspek Hukum dalam Pengadaan Barang dan Jasa Pemerintah", (Paper). Available at: http://www.bppk.kemenkeu.go.id/ Accessed on 10 May 2018.

12. Marzuki, P.M. 2010. Penelitian Hukum. Jakarta: Kencana. hlm 35; compared to Morris L. Cohen dan Kent C. Olson, Legal Reserach in A Nutshell, West Publishing Company, St. Paul Minnesota, p. 1-3.

13. Muhammad Jasin et al. "Memahami untuk melayani, Melaksanakan E-Announcement dan E-Procurement dalam Sistem Pengadaan Barang dan Jasa". Jakarta: Komisi Pemberantasan Korupsi, 2007.

14. OECD. 2007. "Integrity on Public Procurement, Good Practices from A to Z". Paris. Tersedia pada: Piga, G. "A Fighting Chance Against Corruption in Public Procurement?” pada Rose-Ackerman, S. and Soreide, T. (eds.) 2011. International Handbook on the Economics of Corruption, Volume Two, Edward Elgar, Cheltenham

15. Philippe Nonet and Philip Selznik, "Law and Society in Transition: Toward Responsive Law", Harper Colophon Books, Harper \& Row, Publishers, New York, 1978.

16. Richo Andi Wibowo, (Fakultas Hukum Universitas Gadjah Mada dan Utrecht University School of Law), "Mencegah Korupsi Pengadaan Barang Jasa (Apa Yang Sudah Dan Yang Masih Harus Dilakukan?)", https://acch.kpk.go.id/id/ragam/riset-publik/mencegah-korupsi-pengadaan-barang-jasa-apa-yang-sudah-dan-yangmasih-harus-dilakukan, Accessed on 10 May 2018.

17. Romli Atmasasmita, Teori Hukum lntegratif: Rekonstruksi Terhadap Teori Hukum Pembangunan dan Teori Hukum Progresif, Bandung: Genta Publshing, 2012.

18. Sutedi, Adrian. Aspek Hukum Pengadaan Baran dan Jasa dan Berbagai Permasalahannya. Jakarta : Sinar Grafika, 2008.

19. The Study of the Prevention of Corruption for the Procurement of Government Goods and Services, Directorate of Research and Development, December 2014

20. United Nations Office on Drugs and Crime. 2013. "Guidebook on anti-corruption in public procurement and the management of public finances", Source: https://www.unodc.org/documents/corruption/Publications/2013/Guidebook_on_anticorruption_in_public_procurement_and the_management_of_public_finances.pdf, Accessed on 14 April 2018. 